\title{
Romatizmal Kalp Kapak Hastalığı Olan Türk Hastalarda IL-1Ra VNTR Gen Polimorfizminin illişkisi Üzerine Bir Çalışma
}

\author{
A Study on the Relationship of IL-1Ra VNTR Gene Polymorphism in Turkish \\ Patients with Rheumatic Heart Disease
}

\author{
Ayşegül Başak Akadam-Teker ${ }^{1}$ (D), Erhan Teker ${ }^{2,3}$ (i) \\ 'Giresun Üniversitesi, Tıp Fakültesi, Tıbbi Genetik Anabilim Dalı, Giresun, Türkiye \\ ${ }^{2}$ Giresun Üniversitesi A. IIlhan Özdemir Eğitim Araştırma Hastanesi, Kardiyoloji Anabilim Dalı, Giresun, Türkiye \\ ${ }^{3}$ Dr. Ali Menekşe Göğüs Hastalıkları Hastanesi Giresun, Türkiye
}

ORCID ID: A.B.A.T. 0000-0003-3618-0560; E.T. 0000-0002-0234-7548

Cite this article as: Akadam-Teker AB, Teker E. Romatizmal kalp kapak hastalığı olan Türk hastalarda IL-1Ra VNTR gen polimorfizminin ilişkisi üzerine bir çalışma. Experimed 2021; 11(3): 189-94.

\section{öz}

Amaç: Romatizmal kalp kapak hastalığının (RKKH)'da dahil olduğu çeşitli otoimmün ve kronik enflamatuvar hastalıklarda, IL-1 reseptör antagonisti (IL-1Ra) A2 allelinin uzun süreli ve şiddetli proenflamatuvar bağışıklık cevabıyla ilişkili olabileceği yönünde çalışmalar bulunmaktadır. Ancak, RKKH patogenezinde IL-1Ra varyantının ilişkisi ile ilgili çalışmalar oldukça sınırlıdır. Bu çalışmanın amacı, Türk hastalarda IL-1Ra rs2234663 değişken sayıda ardışık yineleme (VNTR) varyantları ile RKKH duyarlılığı ve/veya hastalığın şiddeti arasında bir ilişki olup olmadığını araştırmaktır.

Gereç ve Yöntem: Bu vaka-kontrol çalışmasında (165 RKKH/300 kontrol) IL-1Ra VNTR için polimeraz zincir reaksiyonu (PZR) yöntemi ile genotipleme yapılmıştır.

Bulgular: Hastalar ve kontroller arasında genotip ve allel frekanslarında istatistiksel olarak anlamlı fark tespit edilmiştir $(p<0,001)$. A1 allel frekansı, RKKH hastalarında kontrol grubuyla karşılaştırıldığın$\mathrm{da}$, anlamlı olarak daha yüksek bulunmuştur $(\mathrm{p}=0,004 ; \mathrm{OR}=3,821$; \%95 GA=1,459-10,005). A3 allel frekansı hasta grubunda kontrol grubuna kıyasla istatistiksel olarak anlamlı şekilde artış göstermiştir ( $p=0,034$; $O R=2,536$; \%95 $G A=1,045-6,152$ ). Şiddetli ve hafif kapak hasarı olan hastalar arasında genotip dağılımları istatistiksel olarak anlamlı şekilde farklı bulunmuştur $(p=0,031)$. A2 alleli şiddetli kapak hasarı olan hastalarda hafif kapak hasarı olan hastalara göre istatistiksel olarak yüksek olarak tespit edilmiştir $(p=0,003)$.

Sonuç: IL-1Ra VNTR rs2234663 varyantlarının Türk toplumunda RKKH açısından duyarlı bireylerin tanımlanmasında kullanılabilecek uygun bir biyobelirteç olabileceği önerilmektedir.

Anahtar Kelimeler: IL-1Ra, rs2234663, polimorfizm, romatizmal kalp kapak hastalığı, romatizmal ateş

\section{ABSTRACT}

Objective: There are studies that suggest that the $I L-1$ receptor antagonist $(I L-1 R a)$ A2 allele may be associated with a long-term and severe proinflammatory immune response in various autoimmune and chronic inflammatory diseases, including rheumatic valvular heart disease (RVHD). However, studies on the relationship of the IL-1Ra variant in the pathogenesis of RVHD are very limited. The aim of this study was to investigate whether there is a relationship between IL-1Ra rs2234663 variable number tandem repeat (VNTR) variants and RVHD susceptibility and/or disease severity in Turkish patients.

Material and Method: In this case-control study (165 RVHD/300 controls), we genotyped IL-1Ra VNTR using the polymerase chain reaction (PCR) method.

Results: There was a statistically significant difference in genotype and allele frequencies between patients and controls $(p<0.001)$. The A1 allele frequency was found to be significantly higher in RVHD patients compared to the control group $(p=0.004 ; O R=3.821$; $95 \% \mathrm{Cl}=1.459-10.005)$. The $\mathrm{A} 3$ allele showed a statistically significant increase in the patient group compared to the control group $(p=0.034 ; O R=2.536 ; 95 \% \mathrm{Cl}=1.045-6.152)$. Genotype distributions were statistically significantly different between patients with severe and mild valve damage $(p=0.031)$. The $A 2$ allele was statistically higher in patients with severe valve damage compared to patients with mild valve damage $(p=0.003)$.

Conclusion: IL-1Ra VNTR can be recommended as a suitable biomarker that can be used to identify susceptible individuals in terms of RVHD susceptibility in the Turkish population.

Keywords: IL-1Ra, rs2234663, polymorphism, rheumatic valvular heart disease, rheumatic fever 


\section{GíRiş}

Romatizmal kalp kapak hastalığı (RKKH) otoimmün bir hastalıktır. Romatizmal ateş (RA), A grubu $\beta$-hemolitik streptokokların neden olduğu boğaz enfeksiyonundan sonra antijenler ile konak doku proteinleri arasındaki moleküler taklitten kaynaklanır (1-3). RA'nın en ciddi belirtilerinden olan kardit, hastaların \%30-45'inde ilk atak sırasında gelişebilse de, RKKH çoğunlukla tekrarlayan semptomatik akut RA epizodlarına bağlı kümülatif kapak hasarından kaynaklanmaktadır $(4,5)$. Özellikle gelişmekte olan ülkelerde oldukça ciddi bir sağlık problemi haline gelen RKKH, çocuklarda ve genç yetişkinlerde kalp yetmezliğinin önde gelen nedeni olup, sakatlık ve/ veya erken ölümle sonuçlanabilir. RKKH'da, hastalar kalp yetmezliği ile başvurana kadar tespit edilememektedir. Bu aşamadaki hastalar için tek tedavi seçeneği olan ameliyat ciddi komplikasyonlara sahiptir. Bu ciddi komplikasyonların önlenmesinde nüfusun RKKH için taranması ve duyarlı bireylerin belirlenmesi hastalığın erken teşhis, hedefe yönelik tedavi seçeneklerinin uygulanması için uygun biyobelirteçlerin belirlenmesi oldukça önem arz etmektedir. Diğer yandan, $\beta$ hemolitik grup A streptokok enfeksiyonuna maruziyet sonrasında bireylerin yaklaşık olarak \%3-6'sında RKKH gelişmektedir ve bu durum özellikle son zamanlarda yapılan çalışmalarda bireyler arasındaki genetik farklılıklara atfedilmektedir (6-8). Hastalığın patofizyolojisi henüz tam olarak aydınlatılamamış olsa da çok sayıda sitokin geni RKKH ile ilişkilendirilmiştir. Enflamasyona karşı konak yanıtının ürünleri olan sitokinler, enfeksiyonlara karşı savunmada önemli rol oynamaktadır. Enfeksiyonlar sırasında sitokinler, bağışıklık tepkisinin temel aracılarıdır ve bir dizi uyarıcı veya inhibe edici düzenleyici sinyaller açığa çıkararak çeşitli bağışıklık sistemi hücreleri üzerinde etki gösterirler. Sitokin genlerinde meydana gelen varyasyonların sitokin üretimini ve salgılanmasını etkileyerek bireyin hastalığa olan yatkınlığını, hastalığın şiddetini ve hatta tedaviye yanıtını da etkilediği bilinmektedir. RA/RKKH hastalarında TNF-a, IL-1, IL-6, IFN- $\gamma^{\prime}$ nın da dahil olduğu proenflamatuvar sitokinlerin plazma seviyelerinin yüksek olduğu bildirilmiştir (9-12). Bizim de 2018 yılında yapmış olduğumuz çalışma verileri IFN- $\gamma$ varyantları ve RKKH arasındaki ilişkiyi belgeler niteliktedir (13). İnterlökin-1 (IL-1) gen kümesi, proenflamatuvar sitokin grubundan $I L-1 a, I L-1 \beta$ ve bunların rekabetçi inhibitörü IL-1 reseptör antagonistini (IL-1RA) ifade eden genler kromozom 2 üzerinde yerleşmiştir (14). IL-1Ra geni intron 2'de değişken sayıda ardışık yinelemelere (VNTR) sahip bölgeler içermekte olup bu varyasyon hem IL-1Ra hem de $I L-1 \beta$ üretiminde kantitatif farklılıklara neden olabilmektedir $(15,16)$. IL-1Ra A2 alleli, uzun süreli ve daha şiddetli bir proenflamatuar bağışıklık tepkisi ile ilişkilendirilmiştir. Çeşitli çalışmalarda, IL-1Ra A2 homozigotların RKKH dahil olduğu otoimmün ve kronik enflamatuvar durumlarla bağlantılı olabileceği bildirilmiştir $(17,18)$. Ancak, RKKH patogenezinde IL-1Ra varyantının ilişkisi ile ilgili çalışmalar oldukça sınırlıdır. Biz çalışmamızda, Türk toplumunda IL-1Ra varyantları ile RKKH duyarlılığı ve/veya hastalığın şiddeti arasında bir ilişki olup olmadığını belirlemeyi amaçladık.

\section{GEREÇ VE YÖNTEM}

Çalışma populasyonumuz, Giresun Üniversitesi Tıp Fakültesi kardiyoloji polikliniği tarafından takip edilen baskın mitral darlığı ve hafif-orta derecede mitral yetersizliği ve eşlik eden darlıklı hafif-orta ikinci veya üçüncü kapak hastalığı olan 165 kadın RKKH hastasından (yaş: 50,14 13,99) ve ekokardiyografide kalp kapak hastalığı tespit edilmeyen, otoimmün hastalığı olmayan,

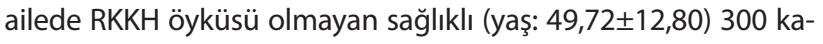
dın kontrolden oluşmaktadır. Çalışmaya dahil edilmeden önce her hasta ve kontrolden bilgilendirilmiş onam alınmıştır. Tüm hastalar transtorasik ekokardiyografi ile 2015 Jones kriterlerine göre RKKH tanısı açısından tekrar değerlendirilmiştir (19). Kapak hasarının ciddiyeti, mitral balon valvotomi (MBV) endikasyonları ve mitral kapak replasmanı (MVR), ACC/AHA/ASE 2003 Ekokardiyografinin Klinik Uygulaması İçin Kılavuz Güncellemesi 2008'e göre değerlendirilmiştir. Kapak lezyonları, ekokardiyografi ile teşhis edilen romatizmal kalp kapak hastalığı, mitral darlık ve/ veya yetersizlik ve eşlik eden hafif-orta dereceli ikinci veya üçüncü kapak hastalığı ile ilişkilidir. Çalışmamızda, dejeneratif aort darlığı olan hastalar göz ardı edilmemiştir. Şiddetli kapak hasarı olan MBV ve/veya MVR olan hastaların klinik ve ekokardiyografik verileri geriye dönük olarak ekokardiyografik verilerden değerlendirilmiştir. Fonksiyonel kapasite New York Kalp Cemiyeti'nin (NYHA) sınıf II - III semptomları, istirahatte pulmoner arter sistolik basıncı $>50 \mathrm{~mm} \mathrm{Hg}$, mitral kapak alanı $<1,5 \mathrm{~cm}^{2}$, hiç olmayan veya hafif-orta mitral yetersizliği olan hastalar ve sol atriyal pıhtısı olmayan ve MBV için uygun kapak morfolojisinin uygun olduğuna karar verilmiştir. Fonksiyonel kapasitesi NYHA sınıf III - IV, mitral kapak alanı $<1,5 \mathrm{~cm}^{2}$ ve pulmoner arter sistolik basınc $>50$ $\mathrm{mm} \mathrm{Hg}$ olan ve orta ila şiddetli mitral yetersizliği olan hastalar MVR gerekliliğinin göstergesi olarak alınmıştır. Hastalar şiddetli

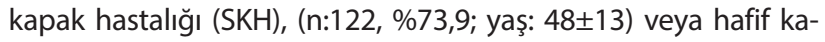

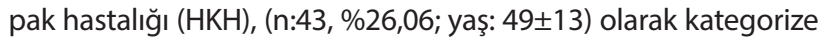
edilmiştir. SKH grubu, MBV ve/veya MVR öyküsü olan hastalardan veya SKH'lı hastalardan ve MVR adaylarından oluşmaktadır. Hastaların 30'unda başlangıçta MVR, 60'ında $(\% 36,36)$ MBV, 26 'sında $(\% 15,15)$ daha sonra MVR gelişti ve 54'ü $(\% 32,72)$ MVR için adaydı. HKH grubu, fiziksel muayeneler ve ekokardiyografik veriler yoluyla hafif-orta şiddetli kapak hastalığı belirtileri nedeniyle tıbbi takipte olan asemptomatik hastalardan oluşuyordu. Ekokardiyografik bulgulara göre; hastalık başvurusundaki hastaların temel özellikleri Tablo 1'de sunulmuştur. Bu çalışmadaki tüm işlemler, kurumsal ve/veya Ulusal Araştırma Komitesinin Etik Standartlarına ve Helsinki Bildirgesine uyumlu olarak gerçekleştirilmiştir (20). Çalışmamız Giresun Üniversitesi Tıp Fakültesi Klinik Araştırmalar Etik Kurulu'ndan alınan (Etik Kurul No: KAEK-121) etik kurul kararınca gerçekleştirilmiştir.

\section{IL-1Ra Genotip Analizi}

Çalışmaya dahil edilen olgulardan alınan periferik kandan ticari kit (Roche high pure isolation kit, Germany) ile DNA izole edilmiş, saflık tayini yapılmış, ve DNA düzeyi hesaplandıktan sonra çalışma zamanına kadar $+4^{\circ} \mathrm{C}$ 'de saklanmıştır. IL-1Ra gen bölgesinin amplifikasyonu için klasik polimeraz zincir reaksiyonu (PZR) yöntemi ve F: 5'-CTCAGCAACACTCCTAT-3' R: 5'-TCCTGGTCTGCAGGTAA-3’ oligonükleotidleri kullanılmıştır. 86 bp'lik 
Tablo 1. Çalışma gruplarına ait karakteristik bilgiler.

\begin{tabular}{|c|c|c|}
\hline Parametreler & Yaş (yıl) & \\
\hline Kontrol $(n=300)$ & $49,72 \pm 12,80$ & $p=0,757$ \\
\hline Hasta $(n=165)$ & \multicolumn{2}{|l|}{$50,14 \pm 13,39$} \\
\hline \multicolumn{2}{|l|}{ Hasta sınıflandırması } & n (\%) \\
\hline \multicolumn{3}{|l|}{ Mitral kapak lezyonları } \\
\hline $\mathrm{HKH}$ & $49 \pm 13$ & $43(\% 26,06)$ \\
\hline SKH & $48 \pm 13$ & $122(\% 73,9)$ \\
\hline \multicolumn{2}{|l|}{ Mitral kapak } & $128(\% 77,5)$ \\
\hline \multicolumn{2}{|l|}{ Mitral Kapak + Aort Kapak } & $37(\% 22,4)$ \\
\hline \multicolumn{3}{|l|}{ Kapak replasmanı (KR) } \\
\hline \multicolumn{2}{|l|}{$\mathrm{KR}+$} & $65(\% 39,3)$ \\
\hline \multicolumn{2}{|l|}{ KR- } & $100(\% 60,6)$ \\
\hline \multicolumn{3}{|l|}{ Valvuloplasti (VP) } \\
\hline \multicolumn{2}{|l|}{ VP+ } & $87(\% 52,7)$ \\
\hline \multicolumn{2}{|l|}{ VP- } & $78(\% 47,2)$ \\
\hline \multicolumn{3}{|c|}{$\begin{array}{l}\text { Ortalama değerler, Student's t-testi kullanılarak hastalar ve kontroller arasında } \\
\text { karşılaştııılmıştır. Niteliksel veriler ki-kare testi ile analiz edilmiştir. Veriler } \\
\text { ortalama } \pm \text { S.D ve n (\%) olarak sunulmuştur. HKH: Hafif kapak hasarı. SKH: } \\
\text { Şiddetli kapak hasarı. }\end{array}$} \\
\hline
\end{tabular}

VNTR içeren IL-1Ra geninin intron 2'si içindeki polimorfik bölge için PZR protokolü; $95^{\circ} \mathrm{C}$ 'de 5 dakika başlangıç denatürasyonunu takiben; 35 döngü halinde $95^{\circ} \mathrm{C}^{\prime}$ de 45 saniye denatürasyon, $55^{\circ} \mathrm{C}$ 'de 45 saniye bağlanma, $72^{\circ} \mathrm{C}$ 'de 45 saniye uzama aşamalarI ve takibinde son olarak $72^{\circ} \mathrm{C}$ 'de 10 dakika olarak gerçekleştirilmiştir. Elde edilen PZR ürünleri \%2'lik agaroz jelde UV altında görüntülenerek genotiplendirme yapılmış ve tekrar sayısına göre alleller karakterize edilmiştir (17). A1 allel (dört tekrar) 410 bp, A2 allel (iki tekrar) 240 bp, A3 allel (beş tekrar) 500 bp'dan oluşmaktadır.

\section{İstatistiksel Analiz}

Bu çalışmanın istatistiksel analizi SPSS 20 paket programı kullanılarak yapılmıştır. Tüm allel ve genotip frekansları doğrudan sayma ile hesaplanmıştır. Hardy-Weinberg dengesi (HWE), Arlequin V3.0 yazılımı kullanılarak hesaplanmıştır (21). Genotip ve allellerin görülme sıklığııın gruplar arası farklııklarının değerlendirilmesinde ki kare $\left(x^{2}\right)$ testi kullanılmıştır. Gruplar arası risk etkeninin belirlenmesi için odds oranı (OR) ve \%95 güven aralığı (\%95 GA) verilmiştir. İstatistiksel anlamlılık sınıı $\mathrm{p}<0,05$ olarak alınmıştır.

\section{BULGULAR}

Çalışmamıza 465 kadın (165 hasta +300 kontrol) birey dahil edilmiştir. Hasta (yaş: 50,14 $\pm 13,39$ ) ve kontrol (yaş: 49,72 $\pm 12,80$ ) grupları arasında yaş açısından istatistiksel olarak anlamlı bir fark bulunmamaktadır. RKKH hastalarında ve kontrollerde IL-Ra VNTR genotip ve allel frekansları Tablo 2'de gösterilmektedir. Hasta grubunda Hardy-Weinberg dengesinden sapma gözlenmiştir $(x 2=4,32 ; p=0,645)$. Bununla birlikte, A1/A1 genotipi RKKH'ya yatkınlık ile ilişkili olduğundan, hasta populasyonunda homozigotluk artışının HWE'den sapmaya neden olan seçimden kaynaklanıyor olabileceği varsayılabilir. Çalışmaya dahil edilen hasta ve

Tablo 2. Hasta ve kontrol gruplarına ait genotip ve allel dağılımları.

\begin{tabular}{|c|c|c|c|c|c|c|c|c|}
\hline \multicolumn{9}{|l|}{ Genotip } \\
\hline & \multicolumn{2}{|c|}{ A1/A1 } & \multicolumn{2}{|c|}{$A 1 / A 2$} & A1/A3 & \multicolumn{2}{|l|}{ A2/A2 } & A3/A3 \\
\hline Hasta $(n=165)$ & \multicolumn{2}{|c|}{$71(\% 43,0)$} & \multicolumn{2}{|c|}{$79(\% 47,9)$} & $10(\% 6,1)$ & \multicolumn{2}{|l|}{$3(\% 1,8)$} & $2(\% 1,2)$ \\
\hline Kontrol $(n=300)$ & \multicolumn{2}{|c|}{$155(\% 51,7)$} & \multicolumn{2}{|c|}{$104(\% 34,7)$} & $19(\% 3,0)$ & \multicolumn{2}{|l|}{$32(\% 10,7)$} & $0(\% 0,0)$ \\
\hline P değeri & \multicolumn{8}{|c|}{$<0,001$} \\
\hline \multicolumn{9}{|l|}{ Allel frekansları } \\
\hline & A1 (+) & A1 (-) & $\mathrm{A} 2(+)$ & A2 (-) & A3 (+) & A3 (-) & A4 (+) & A5 (+) \\
\hline Genel $(n=465)$ & 0,56 & 0,44 & 0,29 & 0,71 & 0,03 & 0,97 & 0,0 & 0,0 \\
\hline Hasta $(n=165)$ & 0,97 & 0,03 & 0,49 & 0,50 & 0,073 & 0,92 & 0,0 & 0,0 \\
\hline Kontrol $(n=300)$ & 0,89 & 0,10 & 0,45 & 0,54 & 0,03 & 0,97 & 0,0 & 0,0 \\
\hline $\mathbf{X}^{2}$ & \multicolumn{2}{|c|}{8,7476} & \multicolumn{2}{|c|}{0,814} & \multicolumn{2}{|c|}{4,507} & & \\
\hline P Değeri & \multicolumn{2}{|c|}{0,004} & \multicolumn{2}{|c|}{0,367} & \multicolumn{2}{|c|}{0,034} & & \\
\hline
\end{tabular}

Veriler $n(\%)$ olarak sunulmuştur. Kalın değerler istatistiksel olarak anlamlıdır $(p<0.05)$. $n$ : örnek sayısı. Tüm alleller allel frekansı şeklinde sunulmuştur. 
kontrol gruplarında 86-bp'lik tekrar sayısının farklılıklarına göre yalnızca üç IL1-Ra VNTR alleli $(A 1, A 2, A 3)$ gözlenmiştir. Türk toplumunda bu allellerin genel populasyondaki frekans dağılımları diğer populasyonlara benzerlik göstermektedir. A1 $(\% 56,9)$ en yaygın alleldir, ardından A2 $(\% 29,9)$ ve A3 $(\% 3,2)$ nadir allel olarak karşımıza çıkmaktadır. Hastalar ve kontroller arasında genotip ve allel frekanslarında istatistiksel olarak anlamlı fark olduğu gözlenmiştir $(p<0,001)$. A1 alleli, RKKH hastalarında kontrol grubuyla karşılaştırıldığında, anlamlı olarak daha yüksek bulunmuştur $(p=0,004 ; O R=3,821 ; \% 95 G A=1,459-10,005)$. A2 alleli hasta ve kontrol grubu arasında önemli bir fark göstermezken ( $p=0,8367$; $\mathrm{OR}=1,191$; \%95 $\mathrm{GA}=0,814-1,743$ ) A3 alleli tüm hasta grubunda kontrol grubuna göre istatistiksel olarak anlamlı şekilde artış göstermiştir ( $p=0,034 ; O R=2,536 ; \% 95 G A=1,045-6,152$ ).

Hasta grubumuzun tamamı kapak hasarı açısından incelendiğinde, şiddetli ve hafif kapak hasarı olan hastalar arasında genotip dağılımları açısından istatistiksel olarak anlamlı farklılık bulunmuştur ( $p=0,031)$.

Hafif ve şiddetli kapak hasarı olan hastalarda IL-Ra VNTR alleli ve genotip frekansları Tablo 3'de gösterilmektedir. A2 alleli şiddetli kapak hasarı olan hastalarda hafif kapak hasarı olan hastalara kıyasla istatistiksel olarak anlamlı derecede farklıdır $(p=0,003)$. $A 1$ ve $A 3$ alleli iki grup arasında istatistiksel olarak anlamlı fark göstermemiştir (sırasıyla, $F E=1,000 ; p=0,050$ ). IL-Ra VNTR alleli ve genotip frekansları kapak replasmanı ve valvüloplasti açısından incelendiğinde gruplar arasında fark bulunmamıştır (data gösterilmemiştir).

\section{TARTIŞMA}

IL-1 reseptör antagonisti, IL 1-a ve IL 1- $\beta$ ile rekabet halinde IL-1 reseptörlerine bağlanabilen, böylece aktivitelerini inhibe eden ve
IL-1 ile ilişkili çeşitli immün ve enflamatuvar aktiviteleri modüle edebilen önemli bir anti-enflamatuvar sitokindir $(22,23)$. IL-1Ra geninde (IL1-RN), intron 2'de üç potansiyel protein bağlanma bölgesi içeren 86 baz çifti tekrarı olan bir VNTR bulunmaktadır. Bu bağlanma bölgesi potansiyel transkripsiyon faktörü bağlanma bölgesinde bulunur ve bu nedenle bu bölgedeki polimorfizmlerin fonksiyonel sonuçlara sahip olması beklenir $(24,25)$. Çalışmalar, RA/RKKH'ya yatkınlığın büyük ölçüde genetik faktörler tarafından belirlendiğini göstermiştir. Bu nedenle, $\mathrm{RKKH}^{\prime}$ ya yatkınlıkla ilişkili konakçı genetik belirteçlerin belirlenmesi, duyarlı bireylerin saptanması için yararlı olabilir. Diğer yandan RKKH ve IL-1Ra varyasyonu ile ilişkili yapılan çalışmalar hem çok sınırlıdır, hem de sonuçları çelişkilidir. Bu nedenle, çalışmamızda Türk toplumunda bu varyasyonun RKKH ile ilişkisini belirlemeyi amaçladık. Çalışmamız, Türk populasyonu için RKKH'da IL1-Ra polimorfizminin etkisini gösteren ilk çalışmadır. Hasta ve kontrol grupları arasında genotip dağılımları açısından anlamIı fark bulunmuştur $(p<0,001)$. Settin ve arkadaşları, 50 Mısırlı çocukta yapmış oldukları çalışmada A1/A1 genotipi ve mitral kapak hastalığı arasında pozitif bir ilişki olduğunu göstermişlerdir (17). Bizim çalışmamızda da bu çalışmayla uyumlu olarak A1 allelinde hasta grubu kontrol grubu ile kıyaslandığında istatistiksel olarak artış tespit edilmiştir $(p=0,003)$. Bu bulgular, Azevedo ve arkadaşları tarafından 84 Brezilyalı RA hastasında A1 taşıma oranı ile A1/A1 genotipi arasında negatif bir ilişkinin bildirildiği çalışma verileri ile çelişmektedir (26). Bu durum, bir genin işlevinin genomik bağlamına bağlı olduğu ve aynı genin farklı ırklarda farklı ifade modellerine sahip olabileceği şeklinde açıklanabilir. İkinci bir adım olarak hasta grubumuzu şiddetli ve hafif kapak hasarı olan hastalar şeklinde ayırdığımızda uzun süreli enflamasyonla ilişkili olduğu bilinen A2 allelinin varlığı şiddetli kapak hasarı olan hastalarda istatistiksel olarak yüksek bulunmuştur $(p=0,003)$. Bulgularımız, Rehman ve arkadaşları-

Tablo 3. Şiddetli ve hafif kapak hasarı olan hastalarda genotip ve allel dağılımları.

\begin{tabular}{|c|c|c|c|c|c|c|c|c|}
\hline \multicolumn{9}{|l|}{ Kapak hasarı } \\
\hline Genotip & \multicolumn{2}{|c|}{ A1/A1 } & A1/A2 & \multicolumn{2}{|c|}{ A1/A3 } & A2/A2 & \multicolumn{2}{|r|}{ A3/A3 } \\
\hline SKH $(n=122)$ & \multicolumn{2}{|c|}{$47(\% 38,5)$} & $66(\% 54,1)$ & \multicolumn{2}{|c|}{$5(\% 4,1)$} & $3(\% 2,5)$ & \multicolumn{2}{|r|}{$1(\% 0,8)$} \\
\hline HKH (n=43) & \multicolumn{2}{|c|}{$24(\% 55,8)$} & $13(\% 30,2)$ & \multicolumn{2}{|c|}{$5(\% 11,6)$} & $0(\% 0,0)$ & \multicolumn{2}{|r|}{$1(\% 2,3)$} \\
\hline P değeri & \multicolumn{8}{|c|}{0,031} \\
\hline \multicolumn{9}{|c|}{ Allel fraksiyonu } \\
\hline & A1 (+) & A1 (-) & A2 (+) & A2 (-) & $A 3(+)$ & A3 (-) & A4 (+) & A5 (+) \\
\hline SKH $(n=122)$ & 0,96 & 0,03 & 0,56 & 0,43 & 0,049 & 0,95 & 0,0 & 0,0 \\
\hline HKH (n=43) & 0,97 & 0,02 & 0,30 & 0,69 & 0,14 & 0,86 & 0,0 & 0,0 \\
\hline $\mathbf{X}^{2}$ & \multicolumn{2}{|c|}{0,098} & \multicolumn{2}{|c|}{8,814} & \multicolumn{2}{|c|}{3,849} & & \\
\hline P değeri & \multicolumn{2}{|c|}{$\mathrm{FE}=1,000$} & \multicolumn{2}{|c|}{0,003} & \multicolumn{2}{|c|}{0,050} & & \\
\hline
\end{tabular}


nın IL-1Ra A2 allelini homozigot taşıyanlarda, RKKH ile ilişkisini bildiren bulguları ile benzerlik göstermektedir (27). Diğer yandan, Çin kökenli Tayvanlı hastalarda IL-1Ra VNTR'nin hastalığın şiddeti ile ilişkisinin olmadığı sonucunu bulan Chou ve arkadaşlarının sonuçları ile çelişmektedir (28).

Bulgularımıza göre, A1 alleli RKKH'a yatkınlıkla ilişkili iken A2 allelinin kapak hasarının şiddeti açısından önemli olduğunu düşündürmektedir. Ancak, bu çalışmada ele alınması gereken bazı sınırlamalar vardır. Çalışmamız; 2019-2020 yılları arasında Giresun Üniversitesi kardiyoloji polikliniğine başvuran RKKH hastalarından oluşmaktadır. Bu dönem içerisinde kliniğe başvuru yapan hasta populasyonu kadın ağırlıklıdır. Bu nedenle istatistiksel güce ulaşmayan erkek hasta populasyonu çalışmadan çıkarılmıştır. Bu nedenle cinsiyet ve IL-1Ra VNTR arasındaki ilişkiyi belirleyemedik. İkinci sınırılığımız, vücut kitle indeksi, enflamasyonla ilişkili biyokimyasal belirteç düzeyleri (CRP, ASO gibi) bulunmadığı için karşılaştırma ve korelasyon yapılamamıştır. Ek olarak, serum IL1 Ra seviyeleri ölçülememiştir. Çalışmamızdaki diğer sınırılığımız, nispeten küçük olan örneklem büyüklüğümüzdür. IL-1Ra VNTR polimorfizminin RKKH gelişimi üzerinde etkisi olup olmadığını belirlemek için çalışmanın daha büyük örneklem grubunda (hasta ve kontrol grupları) yürütülmesi gerekmektedir. Bu nedenle, daha güvenilir sonuçlar elde etmek için IL-1Ra ekspresyon seviyeleri ve RKKH riski üzerindeki etkileri dahil olmak üzere daha büyük örneklem büyüklüğünde daha fazla çalışmaya ihtiyaç vardır.

\section{SONUÇ}

Sonuç olarak çalışmamız, IL-1Ra VNTR'nin RKKH'nın patogenezine katkısının olduğunu doğrulamaktadır. Bireyleri RKKH'a duyarlı hale getiren IL-1Ra VNTR polimorfizmi, RKKH ile ilişkili morbidite ve mortaliteyi azaltmak için profilaktik müdahaleden fayda sağlayacak duyarlı bireylerin belirlenmesi için uygun bir biyobelirteç olarak önerilebilir. Ancak, bu konudaki mekanizmayı tam olarak açıklığa kavuşturmak için daha ileri çalışmalara intiyaç vardır. Bizim çalışmamız, ileride yapılacak çalışmalar için bir ön veri niteliği taşımaktadır.

Hakem Değerlendirmesi: Dış bağımsız.

Etik Komite Onayı: Çalışmamız Giresun Üniversitesi Tıp Fakültesi Klinik Araştırmalar Etik Kurulu'ndan alınan (Etik Kurul No: KAEK-121) Etik Kurul kararınca gerçekleştirilmiştir.

Yazar Katkıları: Çalışma Konsepti - A.B.A.T., E.T.; Veri Analizi/Yorumlama - A.B.A.T.; Yazma: A.B.A.T.; İçeriğin Eleştirel İncelemesi - A.B.A.T., E.T.; Son Onay ve Sorumluluk - A.B.A.T., E.T.

Çıkar Çatışması: Yazarlar çıkar çatışması olmadığını bildirmişlerdir.

Finansal Destek: Bu çalışma Giresun Üniversitesi Bilimsel Araştırma Proje Ofisi tarafından desteklenmiştir (SAĞBAP-A-270220-04)
Peer-review: Externally peer-reviewed.

Ethics Committee Approval: Our study was carried out by the decision of the Ethics Committee of Giresun University Faculty of Medicine Clinical Research Ethics Committee (Ethics Committee No: KAEK-121).

Author Contributions: Conception/Design of Study - A.B.A.T., E.T.; Analysis and/or Interpretation - A.B.A.T.; Drafting Manuscript - A.B.A.T.; Critical Revision of Manuscript - A.B.A.T., E.T.; Final Approval and Accountability - A.B.A.T., E.T.

Conflict of Interest: The authors have no conflict of interest to declare.

Financial Disclosure: This study was supported by $\mathrm{Gi}$ resun University Scientific Research Project Office (SAĞBAP-A-270220-04).

\section{KAYNAKÇA/REFERENCES}

1. Cunningham MW. Rheumatic fever, autoimmunity, and molecular mimicry: the streptococcal connection. Int Rev Immunol 2014; 33(4): 314-9. [CrossRef]

2. Guilherme L, Kalil J, Cunningham M. Molecular mimicry in the autoimmune pathogenesis of rheumatic heart disease. Autoimmunity 2006; 39(1): 31-9. [CrossRef]

3. Poomarimuthu $M$, Elango $S$, Solomon PR, Soundarapandian $S$, Mariakuttikan J. Lack of Association Between TNF- $a$, IFN- $\gamma$, IL-10 Gene Polymorphisms and Rheumatic Heart Disease in South Indian Population. Fetal and Pediatric Pathology 2018; 37: 309-8. [CrossRef]

4. Marijon E, Mirabel M, Celermajer DS, Jouven X. Rheumatic heart disease. Lancet 2012; 10: 953-4. [CrossRef]

5. Guilherme L, Kalil J. Rheumatic fever: from sore throat to autoimmune heart lesions. Int Arch Allergy Immunol 2004; 134: 56-64. [CrossRef]

6. Carapetis JR, Currie BJ, Mathews JD. Cumulative incidence of rheumatic fever in an endemic region: a guide to the susceptibility of the population? Epidemiol Infect 2000; 124: 239-44. [CrossRef]

7. Guilherme L, Ramasawmy R, Kalil J. Rheumatic fever and rheumatic heart disease: genetics and pathogenesis. Scand J Immunol 2007; 66: 199-207. [CrossRef]

8. Engel ME, Stander R, Vogel J, Adeyemo AA, Mayosi BM. Genetic susceptibility to acute rheumatic fever: a systematic review and meta-analysis of twin studies. PLoS One 2011; 6 (9): e25326. [CrossRef]

9. Toor $\mathrm{D}$, Vohra H. Immune responsiveness during disease progression from acute rheumatic fever to chronic rheumatic heart disease. Microbes Infect 2012; 14: 1111-7. [CrossRef]

10. Guilherme L, Kalil J. Rheumatic fever and rheumatic heart disease: cellular mechanisms leading autoimmune reactivity and disease. J Clin Immunol 2010; 30: 17-23. [CrossRef]

11. Col-Araz N, Pehlivan S, Baspinar O, Oguzkan-Balci S, Sever T, Balat A. Role of cytokine gene (IFN-c, TNF-a, TGF-b1, IL-6, and IL-10) polymorphisms in pathogenesis of acute rheumatic fever in Turkish children. Eur J Pediatr 2012; 171: 1103-8. [CrossRef]

12. Van Deventer SJ. Cytokine and cytokine receptor polymorphisms in infectious disease. Intensive Care Med 2000; 26: 98-102. [CrossRef] 
13. Teker E, Akadam-Teker AB, Ozturk O, Eronat AP, Yalin K, Golcuk $\mathrm{SE}$, et al. Association Between the Interferon Gamma $874 \mathrm{~T} / \mathrm{A}$ Polymorphism and the Severity of Valvular Damage in Patients with Rheumatic Heart Disease. Biochem Genet 2018; 56: 225-34. [CrossRef]

14. Hirsch E, Irikura VM, Paul SM, Hirsh D. Functions of interleukin 1 receptor antagonist in gene knockout and overproducing mice. Proc Natl Acad Sci USA 1996; 93 (20): 11008-13. [CrossRef]

15. Tarlow JK, Blakemore Al, Lennard A, Solari R, Hughes HN, Steinkasserer $A$, et al. Polymorphism in human IL-1 receptor antagonist gene intron 2 is caused by variable numbers of an 86-bp tandem repeat. Hum Genet 1993; 91(4): 403-4. [CrossRef]

16. Vamvakopoulos JE, Taylor CJ, Morris-Stiff CJ, Green C, Metcalfe S. The interleukin-1 receptor antagonist gene: a single-copy variant of the intron 2 variable number tandem repeat (VNTR) polymorphism. Eur J Immunogenet 2002; 29(4): 337-40. [CrossRef]

17. Settin A, El-Baz HA, Saber I. Gene polymorphisms of TNF-a-308, IL-10-1082, IL-6-174 and IL-RaVNTR related to susceptibility and severity of rheumatic heart disease. Pediatr Cardiol 2007; 28: 36371. [CrossRef]

18. Witkin SS, Gerber S, Ledger WJ. Influence of Interleukin-1 receptor antagonist gene polymorphism on disease. Clin Infect Dis 2002; 34: 204-9. [CrossRef]

19. Gewitz MH, Baltimore RS, Tani LY, Sable C A, Shulman ST, Carapetis J, et al. Revision of the Jones Criteria for the Diagnosis of Acute Rheumatic Fever in the Era of Doppler Echocardiography: A Scientific Statement From the American Heart Association. Circulation 2015; 131: 1806-18. [CrossRef]

20. World Medical Association. World Medical Association Declaration of Helsinki: ethical principles for medical research involving human subjects. JAMA 2013; 310(20): 2191-4. [CrossRef]
21. Excoffier L, Laval G, Schneider S. Arlequin ver. 3.0: an integrated software package for population genetics data analysis. Evol Bioinform Online 2005; 1: 47-50. [CrossRef]

22. Patterson D, Jones C, Hart I, Bleskan J, Berger R, Geyer D, et al. The human interleukin-1 receptor antagonist (IL1RN) gene is located in the chromosome 2q14 region. Genomics 1993; 15: 173-6. [CrossRef]

23. Carapetis J, Beaton A, Cunningham MW, Guilherme L, Karthikeyan G, Mayosi BM et al. Acute rheumatic fever and rheumatic heart disease. Nat Rev Dis Primers 2016; 2: 15084. [CrossRef]

24. Tarlow JK, Blakemore Al, Lennard A, Solari R, Hughes HN, Steinkasserer $A$ et al. Polymorphism in human IL-1 receptor antagonist gene intron 2 is caused by variable numbers of an 86-bp tandem repeat. Hum Genetic 1993; 91(4): 403-4. [CrossRef]

25. Al-Tahhan M, Etewa RL, El Behery MM. Association between circulating interleukin-1 beta (IL-1 $\beta$ ) levels and IL-1 $\beta$ C-511 T polymorphism with cervical cancer risk in Egyptian women. Mol Cell Biochem 2011; 353: 159-65. [CrossRef]

26. Azevedo PM, Bauer R, Caparbo F, Silva CA, Bonfa E, Pereira RM. Interleukin-1 receptor antagonist gene (IL1RN) polymorphism possibly associated to severity of rheumatic carditis in a Brazilian cohort. Cytokine 2010; 49: 109-13. [CrossRef]

27. Rehman S, Akhtar N, Saba N, Munir S, Ahmed W, Mohyuddin A, et al. A study on the association of TNF-a-308, IL-6-174, IL-10-1082 and IL-1RaVNTR gene polymorphisms with rheumatic heart disease in Pakistani patients. Cytokine 2013; 61: 527-31. [CrossRef]

28. Chou HT, Tsai CH, Chen WC, Tsai FJ. Lack of association of genetic polymorphisms in the interleukin-1beta, interleukin-1 receptor antagonist,interleukin-4, and interleukin-10 genes with risk of rheumatic heart disease in Taiwan Chinese. Int Heart J 2005; 46: 397-406. [CrossRef] 